\title{
Atendimento ao Jovem Homossexual
}

Marcos G. Pragana dos Santos ${ }^{1}$

\section{RESUMO}

SANTOS, M. G. P. Atendimento ao jovem homossexual. R. B. S. H. 1(1): 1990.

Após justificar a importância de um atendimento que cubra a especificidade da parcela homossexual da população jovem, o autor fornece matéria de reflexão sobre a abordagem, colheita de história clínico-sexual, principais patologias, expressão de sua sexualidade, presença de fatores de riscos, aspectos sociais, legais e de postura do profissional de saúde frente à problemática.

\section{INTRODUÇÃO}

Pouco discutido entre profissionais da área de saúde, revelando talvez o preconceito que o tema homossexualidade ainda desencadeia, de maneira generalizada, na sociedade brasileira, 0 atendimento ao jovem homo ou bissexual vem despertando maior interesse em importantes centros acadêmicos no mundo, sendo o assunto recentemente alvo de publicações especializadas, tema de jornadas e simpósios. Tal fato expressa a preocupação não só com as especificidades típicas deste grupo populacional, demograficamente

1. Pediatra, ex-coordenador do Programa Nacional de Saúde do Adolescente do Ministério da Saúde, Coordenador do Setor de Saúde do IAM do Paraná. 
significativo, como também pela razão de que indivíduos destes grupos adentram, com muito maior freqüência do que já é comum à juventude, em sérias situações de risco.

Se o assunto é polêmico, é justamente numa publicação de seriedade científica incontestável como é esta que ele deve ser divulgado. A partir deste artigo, os leitores se sensibilizarão, refletirão, amadurecerão e discutirão idéias, no sentido de apresentar soluções à problemática levantada, sendo os indivíduos pertencentes ao grupo populacional em discussão os que mais lucrarão com estes atos, 0 que reverterá em direção à sociedade como um todo.

\section{ABORDAGEM, COLHEITA DE HISTÓRIA, CONDUÇÃO DA CONSULTA}

Enunciamos, logo de início, que qualquer profissional que lide com jovens deve estar técnica e psicologicamente apto para realizar um levantamento da história sexual do indivíduo. Esta deve ir além da simples abordagem superficial do tema. Tal fato facilitará não somente chegar-se a conclusões diagnósticas mais acuradas, como também a orientação a aconselhamento do jovem no sentido de uma prática sexual mais segura, responsável, livre de riscos e, portanto, mais saudável.

Já existe da parte do jovem uma certa desconfiança em relação ao profissional, exacerbação do delírio persecutório, quando fantasia que; como adulto, o profissional é um representante da ordem estabelecida, da moral e dos bons costumes, estando ali apenas para descobrir e denunciar os mais íntimos segredos do jovem. Assim é que este teme submeter suas vivências e o direcionamento de seus impulsos sexuais ao crivo crítico daquele estranho.

Jovens, em geral, e jovens homossexuais, em particular, são verdadeiros desafios ao clínico, porque sua sexualidade emergente está associada a intensas reações emocionais (do próprio adolescente, mas também do adulto frente a este desabrochar do jovem). Desta maneira, um jovem pode não associar ou mesmo negar que determinada condição precária de saúde esteja relacionada às suas práticas sexuais, ou, ao contrário, devido a má informação geral sobre o tema, pode fantasiar que determinado problema de saúde advém de práticas totalmente alheias, mas que ele imputa a expressão de sua sexualidade, vindo a esconder essa doença (principalmente em ambientes onde o sexo envolve forte noção de pecado, fruto proibido, gerador de fortes sentimentos de culpa, mas também de curiosidade e prazer de aventura). 
Assim sendo, nunca será demais alertar sobre a necessidade de criação de um bom vínculo com o jovem, o que não se dá tão rapidamente, apesar de muitas vezes haver pressa em se chegar a um diagnóstico preciso e encerrar o tratamento correspondente. Portanto, há que se ter muita paciência, saber reconhecer o tipo de personalidade do jovem que está ali a nossa frente, esquematizar uma estratégia de abordagem a partir destes dados e, em se tratando de assuntos extremamente mobilizantes, como homossexualidade, saber reconhecer o mote, a dica, a deixa, o momento exato (timing) que permitirá a abordagem desses temas. Esta deve ser direta: floreios e dissimulações podem denotar uma dificuldade do profissional em lidar com o tema, facilmente percebida (quando não, até ironizada) pelo altamente crítico jovem.

A linguagem usada pelo profissional deve ser muito bem dosada. Não vamos chegar ao exagero de propor uma "higienização lingüística”, pois também de nada adiantará falar de maneira pomposa ou com uma enchurrada de termos científicos que não serão compreendidos pelo jovem. O uso de termos fortes da parte do profissional pole passar uma idéia de rotulação e assustá-lo, daí ser contraproducente recorrer a termos como "bicha", "gay", "desmunhecado", "machona" ou "sapatão". Até porque, estes esteriótipos são uma minoria entre os homossexuais, pequena ponta aparente de um grande iceberg submerso.

Eis alguns exemplos de perguntas diretas, porém atenuadas, geralmente bem aceitas pelos jovens na colheita de informações sobre o direcionamento de seus instintos libidinosos:

- "Ultimamente você tem transado com pessoas do sexo oposto, do mesmo sexo, dos dois sexos ou não tem transado?'

- "Você acha que tem algum fato especial relacionado às suas práticas sexuais que se relacione com as queixas que você me apresenta sobre a sue saúde?"

- "Se você fosse o médico e quisesse esclarecer melhor seu problema de saúde, pediria apenas uma cultura de secreção do seu pênis, ou acharia melhor também colher material do ánus e da boca?'

Uma vez obtida a confirmação (e não a "confissão") da atividade sexual do jovem paciente, o profissíonal deve ir gradativamente se aprofundando em questões que esclareçam melhor sobre a maneira como o jovem vem exercendo essa atividade, com vistas até a facilitar conclusões diagnósticas, localizações de lesões, pistas sobre agentes etiológicos e mesmo a detecção de situações de risco. Portanto, quando falamos em colheita de história sexual, ressaltamos a 
necessidade de se incluir ai um profundo levantamento das práticas sexuais.

\section{Assim É Que Se Deve Pesquisar}

- Tipos de relação homossexual

- Freqüência

- Posições

- Parceiro único ou múltiplos

- Parceiro conhecido ou anônimo

- Prostituição

- Travestismo

- Assalto ou abuso sexual

- Prática de sexo oral

- Introdução de corpos estranhos

- Se partilha estes com outras pessoas

- Hábitos de higiene pré e pós-coitais

- Uso de lubrificantes e escarificantes químicos

- Práticas sado-masoquistas

- Uso concomitante de álcool e drogas

- Horários e locais onde costuma freqüentar na busca de parceiros

Um profissional competente não deve se contentar com respostas curtas, do tipo "sim", "não" ou "talvez", sendo necessário o maior detalhamento possível. Também não deve se chocar ou se surpreender (e se isso acontecer, tentar não demonstrar o fato ao jovem paciente) com os achados nessas respostas pois, atualmente, os vários grupos de homossexuais vêm empregando uma ampla gama de estratégias e variações na busca de estímulos, práticas estas que vão muito além dos clássicos papéis "ativo" e "passivo".

Quanto à jovem lésbica, ela também pode estar preocupada com o tipo de aproach com o qual o profissional irá brindá-la. Se este for apressado e inexperiente ao inquiri-la se é ou não sexualmente ativa, ao receber resposta positiva, pode enveredar por caminhos errados, dirigindo a consulta para assuntos que pouco podem interessá-la, sobre anticoncepção, por exemplo. Esta jovem pode, na verdade, ter procurado o serviço com o intuito de saber a possibilidade de inseminação artificial, de adoção de uma criança ou, talvez, sobre o problema da custódia de filhos de um fracassado relacionamento heterossexual anterior.

O profissional deve ter em mente que o fato de estar frente a 
uma jovem lésbica não se lhe dispensa os cuidados de saúde a que tem direito qualquer mulher, lembrando mesmo que o câncer cérvico-uterino e de mama são mais freqüentes entre as mulheres que nunca engravidaram ou amamentaram. A realização de exames preventivos e o ensino da palpação da mama para a jovem lésbica, assim como o auto-exame dos testículos para rapazes homossexuais, no sentido da detecção precoce do desenvolvimento de massas neoplásicas nestes locais, segue os mesmos preceitos do atendimento a qualquer outro jovem.

Se a anamnese deve ser acurada, não menos deverá ser o exame físico, inclusive no que diz respeito à palpação e à inspeção externa e interna das genitálias e da região anal. Entretanto, exames mais invasivos, como toques retais e vaginais, só deverão ser realizados numa primeira consulta, se houver menção de queixas que justifiquem tais procedimentos, devendo-se aguardar a criação de um clima de maior confiança que permita realizá-los numa segunda ou terceira visita ao consultório. Mesmo assim o profissional deve antes explicar ao paciente como será realizado tal procedimento, através do uso de modelos ou esquemas anatômicos (que por sinal não devem ficar à mostra, o que pode chocar ou assustar o jovem, só aparecendo quando necessário), deixando o jovem examinar a aparelhagem a respondendo suas dúvidas. Tal conduta serve para baixar 0 limiar de ansiedade que a expectativa do desconhecido pode causar. Exames mais agressivos, como biópsias, retossigmoidoscopias, curetagens etc., devem ser encaminhados para a realização em locais especiais, mais apropriados.

Antes de se dar uma hipótese diagnóstica fria e pronta, perguntar ao jovem o quanto esse fato o preocupa ou aborrece, qual a gravidade que o jovem imputa ao problema, tranqüilizá-lo a dizer-se capaz de ajudá-lo, contando com a indispensável ajuda dele próprio. A importáncia do cumprimento de prescrições e exames complementares deve ser exaustivamente explicada, estimulando 0 jovem a se responsabilizar por sua própria saúde.

\section{PROBLEMAS CLINICOS MAIS FREQÜENTES ENTRE JOVENS HOMOSSEXUAIS (em ordem de freqüência)}

- Doenças sexualmente transmissíveis (D.S.T.) ditas "clássicas"

- Desordem do aparelho digestivo

- Complicações traumáticas do intercurso sexual

- Deficiências adquiridas da imunidade celular (serão apresentadas, por questão didática, junto a D.S.T.) 
- Problemática psico-social (não está na ordem de freqüência por ser geral, estando destacada por questões didáticas)

Obs.: Nenhum desses temas será aqui esmiuçado, dando-se apenas destaque a especificidade quando de sua ocorrência em grupos homossexuais jovens.

\section{Manifestações das D.S.T. Ditas “Clássicas”}

(em ordem de freqüência)

- Infestações Ectoparasitárias

- Uretrites/Vulvoginites

- Proctites (pertencente também ao grupo de doenças entéricas mas incluídas neste grupo por motivos didáticos)

- Lesões Dermatológicas

- Ano-retais: Ulcerosas

- Difusas

\section{Verrucosas}

- Outras

- Manifestações Orofaríngeas

Devido a uma liberação dos costumes, não acompanhada de uma carga correspondente de informações, as D.S.T., que estavam diminuindo drasticamente desde o início do uso de quimioterápicos e antibióticos na década de 40, voltaram a recrudescer a partir dos anos 60, chegando-se a uma verdadeira epidemia na primeira metade da década de 80. O pânico instalado quando o mundo (principalmente a comunidade homossexual) se conscientizou, através da AIDS, do risco que corria (até certo ponto, e talvez muito pouco entre os jovens), passando a tomar precauções a respeito, chegou-se, não a uma queda mas, ao menos, a uma estabilização na incidência de D.S.T. na segunda metade da década de 80. Dados da OMS informam que de 60 a $70 \%$ dos casos de D.S.T. incidem sobre jovens abaixo de 25 anos.

A reboque das pesquisas sobre AIDS, pela primeira vez houve preocupação em se levantar a incidência de D.S.T. "clássicas" em grupos homossexuais, o que até certo ponto denota um certo desprezo e preconceito em relação a esse grupo populacional.

Pesquisas recentes, realizadas nos E.U.A., Inglaterra, Alemanha e outros países, revelaram que se a situação entre heterossexuais foi e de um crescimento anual da incidência destas doenças em progressão aritmética, entre homossexuais, provavelmente por uma questão de estilo de vida deste grupo (não gostaríamos, mas é inevitável usar a palavra "promiscuidade"), a progressão foi geométrica, 
sendo 300\% maior que entre heterossexuais. Cerca de 60 a $80 \%$ dos indivíduos homossexuais são ou foram portadores, sintomáticos ou não, de um ou mais dos cinco mais freqüentes agentes etiológicos causadores de D.S.T.

Da mesma forma, com as mudanças de hábitos sexuais na busca de maior prazer, apontados em relatórios, como os conhecidos Kinsey e Master-Johnson, feitos em anos diferentes e que assim proporcionavam condições de comparação, pode-se constatar, por exemplo, maior freqüência de parceiros múltiplos e anônimos, prática do felácio e anilíngus com o correr dos anos, fatores que contribuíram inevitavelmente para o incremento tão dramático das D.S.T. entre homossexuais, assim como de outras doenças, como a hepatite.

Existe, entre homossexuais, uma série de problemas além daqueles já encontrados entre heterossexuais, como vergonha de ir ao médico, apelo para automedicação, tratamentos feitos através de facultativos em balcões de farmácia e o fato de acharem que se curaram quando, freqüentemente, passado o período agudo inicial, algumas D.S.T. recolhem seus sintomas mas o indivíduo permanece portador a transmissor sem o saber, até uma futura recidiva. Vale relatar, por exemplo, que a localização anal de certas lesões freqüentemente observadas entre homossexuais, mesmo que ativas, são de difícil visualização a constatação. Isso os transforma mais facilmente em transmissores potenciais.

Após este preâmbulo retomamos as formas mais freqüentes com que as D.S.T. ditas "clássicas" se apresentam.

\section{Infestações Ectoparasitárias}

- Phitiríase (chato)

- Pediculose (piolho)

- Escabiose (sarna)

Não são propriamente D.S.T. mas, muito freqüentemente, ligadas a este tipo de transmissão.

Uretrites, Vaginites e Proctites

- Gonocócicas

- Não Gonocócicas: Clamidea tracomatis

Cepas do linfogranuloma venéreo

Traumáticas

Alérgicas

Outras 
Quanto às uretrites gonocócicas, chamamos atenção para a incidência destas entre homossexuais, que é muito mais alta que a incidência entre heterossexuais que, ao contrário e em se tratando de uretrite não-gonocócica, têm uma proporção maior de uretrites causadas pela Clamidea tracomatis, extremamente rara entre homossexuais. Portanto, frente ao homossexual portador de uretrite não-gonocócica, pensar em outras etiologias como Stafilococus aureus e S. epidermites ou Proteus mirabilis. Não se justifica a pesquisa da Clamidea como rotina, pela sua baixa freqüência (como se faz no paciente heterossexual), devido ao alto preço e às dificuldades de realização deste exame. Quando infectados por Clamidea, geralmente esta é da cepa que se traduz freqüentemente de maneira muito mais gritante, através do linfogranuloma venéreo.

Chama atenção o fato de que em pacientes com hábitos de penetração anal ativa, em relacionamento homo ou heterossexual (porém mais freqüente no primeiro grupo), geralmente após a uma uretrite, segue-se uma infecção urinária alta, sendo necessário após o tratamento daquela realizar-se de rotina um exame parcial de urina e cultura, pois são freqüentes infecções por coliformes.

Quanto às uretrites traumáticas, estas são muito freqüentes em adolescentes e jovens devido a intensa atividade masturbatória, assim como, pelo temor de terem pego uma D.S.T., quando ficam se verificando a toda hora, espremendo o pênis a procura de sinais de secreção.

Em relação às vaginites devido a D.S.T. entre lésbicas, estas são raras, principalmente se levando em conta as de etiologia bacteriana que, quando ocorrem, foram geralmente adquiridas em eventuais relações heterossexuais.

Quanto às vaginites, assim como uretrites e proctites de causa alérgica e traumática, são de muito maior incidência entre homossexuais devido ao freqüente emprego de lubrificantes e escarificantes químicos que facilitam a introdução ano-peniana e produzem um aumento de sensações prazeirosas. A própria borracha do condom e mesmo as secreções do próprio paciente, como as de seu parceiro, podem ser causa de fenômenos alérgicos.

Em relação às proctites, a maioria delas tem como agente etiológico a Neiseria gonorreae em homossexuais masculinos, geralmente são assintomáticas, quando muito, levando a discreto prurido anal e a certo grau moderado de secreção. Quando há infecção extensa, pode, entretanto, apresentar uma sintomatologia mais grilante, como tenesmo, abundante secreção purulenta e com mau cheiro, eliminação de sangue se ocorrerem micro-ulcerações na mucosa 
ano-retal. O mesmo pode acontecer se a infecção tiver cepas linfogranulomatosas de Clamidea como agente etiológico.

\section{Lesões Dermatológicas}

Ano-genitais

- Ulcerativas

- Cancro sifilítico (Treponema pallidum)

- Herpes simplex vírus

- Cancro por Haemofilus dulcreiy (diagnóstico diferencial com carcinoma, lesões extensas e profundas)

- Papulares

- Condiloma sifilítico

- Condiloma plano (Papiloma vírus)

Difusas

- Sifílides, gomas, rash sifilítico (diagnóstico diferencial com citomegalia e mononucleose)

- Micoses (Tíneas, Ptiríase versicolor)

- Molusco infeccioso

Outros (Não são relacionadas diretamente com D.S.T. mas estão muito ligadas à condição homossexual do indivíduo.)

- Eczemas

- Queimaduras químicas

A mais freqüente lesão ulcerativa ano-genital por D.S.T. é uma manifestação primária da sífilis, o cancro inicial da infecção por Treponema pallidum, geralmente único e assintomático. Lesões iniciais carcinomatosas podem ser confundidas com o cancro sifilítico.

A segunda causa mais freqüente são as lesões herpéticas, pruriginosas, múltiplas e menores, mas que, em conjunto, podem confundir-se com uma lesão cancróide. Entre homossexuais, ainda que raras, são mais freqüentes que entre heterossexuais complicações graves desta infecção, como a mieloradiculopatia e a meningomielite, ambas se iniciando por manifestações de intensa dor ciática e posteriormente parestesias nos membros inferiores, a partir das extremidades, passando a disfunção urinária e incontinência fecal, não raro terminando em quadro meníngeo de evolução grave, apesar da etiologia viral.

Num distante terceiro lugar o Haemofilus ducreiy aparece como responsável por lesões ulcerosas ano-genitais, a também por lesões cancróides que, ao contrário da sífilis, ocorre geralmente em forma de epidemias circunscritas a determinadas áreas geográficas, 
por período que raramente ultrapassa 18 meses, sendo geralmente de 6 a 8 meses.

As lesões papulares ou verrucosas aparecem na forma de condilomas, mais freqüentemente, uma manifestação secundária da sífilis. Já o condiloma plano tem o papiloma virus como agente etiológico a nem sempre sua transmissão é por via sexual. De forma geral, mas com maior freqüência entre homossexuais, tem-se relacionado o aparecimento de carcinoma a uma lesão prévia pelo papiloma virus no mesmo local.

Quanto às lesões dermatológicas difusas, as mais freqüentes são manifestações secundáris da sífilis, sob as mais variadas formas: sifílides, alopécias, gomas e rash cutâneo, este último podendo mimetizar citomegalia ou mononucleose ("doença do beijo", ou "dos estudantes", também muito freqüente entre homossexuais), pois acompanha-se de infartamento ganglionar generalizado, febre e, por vezes, hepato-esplenomegalia. Todas essas três entidades nosológicas, raramente mas com maior freqüência entre homossexuais, podem mimetizar uma hepatite, pois acompanham-se de icterícia.

Outras lesões difusas, mas não exclusivamente de transmissão sexual, são a ptiríase versicolor, as tíneas (mormente a Tinea cruris) e o molusco infeccioso que podem, entretanto, ser altamente sugestivos desta via de contágio quando incidem no grupo populacional em estudo. Manchas vinhosas, que se iniciam de maneira centrífuga e depois se generalizam, podem sugerir complicações da AIDS, principalmente nas faixas etárias superiores próximas a idade que separa a juventude da vida adulta (em torno dos 25 anos).

Não inerentes à transmissão sexual, mas sim à condição homossexual do indivíduo, estão as lesões correspondentes a queimaduras químicas nas narinas, geralmente associadas a um grupo de sinusites químicas, proveniente do largo uso entre certos grupos de homossexuais mais jovens dos rush-poppers (a "droga das discoteques"), obtidos a partir de medicamentos usados como cardiodilatadores derivados de nitritos, assim como o uso de inalantes do tipo de desodorantes de ambientes nitrogenados e lança-perfume. Estas substâncias são usadas não só com a finalidade de levar à sensação de êxtase a tranqüilidade, mas também porque levam a um relaxamento do esfíncter anal e a um rápido esvaziamento da próstata, que facilita a penetração e o orgasmo. A over-dose dessas substâncias leva, geralmente, à parada cardíaca e seu uso constante ou exagerado pode levar a .meta-hemoglobinemia.

Entre sadomasoquistas, são encontrados hematomas, manchas equimóticas, queimaduras, lesões mais ou menos profundas e escarificações da pele. 
Sendo freqüente o uso de cosméticos por outros grupos de homossexuais, não raro encontram-se eczemas e reações alérgicas resultante do uso de esmaltes, rímel, blushes, sombras, pós, bases, tinturas e fixadores para cabelo, alguns tipos de bijuterias, lesões que podem ser localizadas ou generalizadas, estas últimas, freqüentemente pelo uso de fórmulas caseiras de bronzeadores.

Manifestações Orofaríngeas das D.S.T.

- Faringites e Estomatites (Neiseria gonorreae)

- Lesões Ulcerativas (Treponema pallidum, Haemofilus ducreiy, Herpes)

- Lesões Verrucosas (Treponema p.)

- Lesões Resultantes da Infecção por H.I.V.

- Leucoplaquias

- Candidíase oral disseminada e repetitiva

- Sarcoma de Kaposi

A gonococcia é a infecção mais freqüente entre as manifestações orais da D.S.T., geralmente assintomática, cerca de 16 a 20\% de homossexuais apresentam essa condição, daí ser rotina fazer-se cultura do swab bucal. Outras vezes ela pode se manifestar na forma de faringite clássica ou, menos freqüentemente e quando há infecção extensa, na forma de sinais de estomatite, gengivite, piorréia e glossite.

Entre as lesões ulcerosas mais freqüentes está o herpes labial, nem sempre de transmissão por via sexual, mas sugestivo quando entre homossexuais, ao contrário do cancro e do condiloma sifilítico de localização oral, que tem sempre esta via de transmissão.

Cabe aqui citar apenas algumas manifestações orais associadas à infecção por H.I. V., como a leucoplaquia, a infecção repetitiva e disseminada por monilia a lesões típicas do sarcoma de Kaposi.

Não vamos entrar em maiores considerações sobre as infecções por H.I.V., causadores da Síndrome Imunológica de Deficiência Adquirida (SIDA/AIDS), que se manifesta clinicamente através de uma plêiade de doenças oportunistas, entre elas a pneumonia por Pneumociste carinii e a toxoplasmose, além das que se encontram mencionadas neste texto.

Lembraríamos apenas que não é somente este tipo de virus que leva a imunodeficiência. O próprio vírus da hepatite tipo $\mathrm{B}$, que abordaremos mais adiante, também o é, assim como o sêmem do parceiro depositado no ânus, que durante o intercurso sexual pode ser absorvido pela mucosa ou através de micro-lesões e fissuras, entrando na circulação, não sendo reconhecido como self e 
causando danos ao sistema imunológico. Da mesma forma, alguns homossexuais passam horas expostos à inclemência do tempo, nas ruas, à noite, sem horários, alimentando-se mal, desgastando-se fisicamente etc.

Em relação às D.S.T., orienta-se ao profissional não dirigir os exames laboratoriais apenas às necessidades trazidas pelo paciente $\mathrm{e}$ aos achados do exame físico, pois é necessário, nestas condições, detectar os casos assintomáticos. Deve-se obrigatoriamente, frente a um jovem confessamente homossexual, solicitar, de rotina, uma cultura de material obtido através de swab uretal, anal e bucal; sorologia para lues e para hepatite tipo B.

Em relação aos testes para a detecção de infecção por H.I. V., a possibilidade e a importância de sua realização deve ser apresentada a todo homossexual/bissexual, deixando, entretanto, a escolha a critério do próprio paciente nesta questão por demais mobilizante. Além disso, em se tratando de um jovem, lembramos que a grande incidência de positividade a estes testes é mais encontrado em pacientes acima de 25 anos. Abaixo desta idade também encontra-se positividade, mas muito freqüentemente teve-se como via de infecção o uso de drogas endovenosas com compartilhamento de seringas e agulhas, não estando descartada, absolutamente, a possibilidade do contágio por via sexual. A grande importância da abordagem sobre AIDS com jovens, principalmente aqueles que não se iniciaram sexualmente, é porque nessa fase formam-se hábitos que são carregados ao longo da vida, daí a necessidade de trabalho preventivo desde então (e até mesmo antes...).

Por este motivo cremos ser extremamente importante que se encete uma meta de educação para saúde a longo prazo, iniciando-se nos lares, através dos pais, seguindo-se na escola, principalmente entre escolares pré-adolescentes, pois estes já têm um bom nível de entendimento dos tópicos, sem ainda estarem expostos a eles. Nesta abordagem deve-se preocupar em não ser moralista, para não se correr o risco de tampar o sol com a peneira ou ser alvo fácil de chacota por parte do jovem, mas ser realista. Somente desta maneira conseguiremos passar aos jovens noções no sentido da detecção de situações de risco e do posicionamento frente a estas, to mando atitudes positivas. E isso não apenas na área da sexualidade - D.S.T./AIDS, concepção/anti-concepção, paternidade responsável, dificuldades e problemas sexuais, incluindo-se ai a homossexualidade -, mas em muitas outras áreas: acidentes, por exemplo.

Lembremos que, frente a uma D.S.T., não cabe apenas ao profissional tratá-la, indo seu trabalho muito além disso, como a 
notificação da incidência das doenças às autoridades sanitárias. Um pouco mais difícil será convencer o paciente da necessidade de comunicar o fato, se possível, a seus contatos. Outro ponto é conscientizar o paciente da necessidade de um período de abstinência durante o tratamento, até que exames se negativem a este obtenha alta. Por fim, tentar impedir a re-infecção, muito freqüente, através do incentivo ao uso de (e do acesso a) métodos preventivos, como o condom, que tem uma falha média para D.S.T. de apenas $3 \%$, fato que o indica como um método seguro. Isto, apesar de toda a dificuldade deste trabalho com jovens, que estão presos a tabus como o fato de considerarem que "camisinha corta o barato", somado a uma precária noção de casualidade, a uma ainda alta carga de onipotência, ao fato de não saberem esperar (nem que seja alguns minutos até se chegar a uma farmácia próxima), torna esta uma tarefa árdua,

O estardalhaço (justificável) em torno da AIDS nos preocupa pois, se por um lado ajudou no decréscimo da ocorrência das D.S.T. ditas "clássicas", o uso de preservativos ficou muito ligado à imagem da primeira. Tememos que, encontrada a cura ou uma vacina para a AIDS, tal fato leve ao afrouxamento do uso de preservativos, voltando a acontecer um novo boom na incidência de D.S.T. ditas "clássicas".

\section{Doenças Entéricas}

- Proctites (já comentadas)

- Colites e Enterites

- Bacteriana: Sheguela

Salmonela

Campilobater

- Proto-Parasitária: Entamoeba h.

Giardia 1.

- Fúngica: Candidíase disseminada

- Hepatites

- Tipo A

- Tipo B

- Tipo não-A não-B

As colites e as enterites podem se expressar de maneira branda ou exacerbada, levando a um quadro diarréico, de duração breve ou prolongada. Diarréias mais exacerbadas podem se complicar com quadros de desequilíbrio hidreletrolítico (desidratação) a ácido-básico (acidose metabólica). As mais prolongadas levam a intenso qua- 
dro de emagrecimento e astenia (síndrome desabsortiva).

Na dependência do agente etiológico em voga, pode freqüentemente haver a condição de portador assintomático entre jovens homossexuais. Via de regra a transmissão é oro-fecal. Os agentes bacterianos mais freqüentes são a Shiguella e a Salmonela seguidas, num distante tenceiro lugar, pelo Campilobacter jejuni. Tratando-se geralmente de infecções autolimitadas, não ultrapassa de 7 a 10 dias. De qualquer forma é interessante realizar-se coprocultura após a regressão dos sintomas visando detecção desses portadores assintomáticos.

Quanto à etiologia proto-parasitária, temos a Entarmoeba histolitica e a Giardia lamblia como principais agentes, tratando-se de germes oportunistas, o que não deve ser esquecido ao lidarmos com pacientes portadores de baixa imunidade e mal estado geral, podendo inclusive evoluir para quadros metastáticos extremamente graves, como nos casos de abcessos hepáticos ou cerebrais, e amebíase cutânea (lesões em botão de camisa).

Por fim, temos a Candida albicans, levando a irritação extensa do trato gastroentérico, como principal causa de colites e enterites de etiologia fúngica. Tal quadro leva a uma síndrome desabsortiva, comum entre portadores de H.I. V. que apresentam queda de imunidade. Trata-se de diarréias prolongadas.

Quanto às hepatites, estas podem evoluir assintomaticamente, sub-clinicamente (forma anictérica) ou apresentar um quadro florido. A incidência de hepatite entre homossexuais jovens é três vezes maiór do que entre a população geral e, se considerado os casos de hepatite $\mathrm{B}$, esta proporção pode ser bem mais alta. $\mathrm{O}$ grupo mencionado está mais exposto não apenas pelo fato de uma maior freqüência de performances sexuais entre alguns grupos de homossexuais, mas também pela freqüência a ambientes de alta probabilidade de contaminação, como saunas e banheiros públicos.

Lembramos que a hepatite tipo B pode evoluir num transcurso crônico com fases de reagudização. Não raro, há evolução para a necrose hepática e posterior aparecimento de carcinoma.

\section{Complicações Traumáticas}

Contrariando crença generalizada, o intercurso sexual por via anal não é causa freqüente de lesões macromórficas do esfíncter anal e botões hemorroidais. $\mathrm{O}$ uso de lubrificantes no intercurso sexual, muito difundido entre homossexuais, diminui essa possibilidade, mas infelizmente são, em geral, substâncias altamente cancerígenas, se usadas com freqüência, principalmente os derivados de petróleo (va- 
selinas etc.). Os cremes menos agressivos seriam os aquosos e naturais, como os cremes de aveia, óleos vegetais ou o $\mathrm{K}-\mathrm{Y}$, este último não existente no Brasil.

Somente nos casos de introdução de corpos estranhos extremamente volumosos ou perfurantes, nos casos de estupros a prãticas sado-masoquistas que envolvem violência, pode-se induzir a traumas na região ano-retal, que se traduzem principalmente por fissuras a esgarçamentos, levando a incontinência fecal ou ao prolapso hemorroidal, este último podendo evoluir para trombose e posterior necrose.

Frente a uma copiosa hemorragia, antes de se pensar em uma lesão baixa, há que se encaminhar este paciente com urgência para realização de uma retossigmoidoscopia, onde geralmente a lesão será encontrada bem acima do nível dos botões hemorroidais, nunca tendo um intercurso sexual como causa e, sim, a introdução de corpos estranhos.

Por ser a região ano-retal um local muito infectado, fissuras ai localizadas podem, com freqüência, se infectar, abcedar e evoluir posteriormente para a fistulização.

Corpos estranhos na ampola ano-retal (ou mesmo acima desta), tais como "consolos", vibradores, frascos cilíndricos e até garrafas de pequeno porte são encontradas no atendimento ao grupo homossexual. Não são, porém, exclusivos deste: muitos heterossexuais também usam esta técnica como fonte de obtenção de prazer.

A remoção destes objetos pode se dar com maior ou menor facilidade. Garrafas de certas marcas de refrigerantes, se presas por pressão negativa, já possuem em seu fundo uma pequena região circular onde o vidro é menos espesso. Quebrada neste local, a garrafa desprende-se, evitando estilhaçar-se inteira, o que exigiria uma delicada remoção dos cacos, com possibilidades de danos maiores. Estando a remoção difícil, encaminha-se o paciente para uma cirurgia proctológica. Se o corpo estranho estiver preso por simples espasmo anal, se desprenderá logo após o ato anestésico que provoca relaxamento do esfíncter, evitando-se a cirurgia.

Lembrando que a introdução de objetos estranhos muito volumosos ou, por exemplo, na prática do fisting quando há introdução do punho ou até mesmo do braço todo no ânus), a dilatação do esfíncter pode levar a uma parada cardíaca por mecanismo de reflexo vagal.

No caso de lacerações com abundante sangramento, o quadro pode complicar-se pela instalação rápida de choque hipovolêmico ou, um pouco mais tardiamente, de um choque septicêmico, devendo-se tomar as devidas e imediatas precauções relativas a estes fatos. 
Sendo comum entre os jovens em geral, por motivos mecânicos, o edema peniano (resultante de uma intensa atividade masturbatória) pode ser encontrado com freqüência maior entre homossexuais, pelo fato das penetrações anais serem mais vigorosas. $\mathrm{O}$ tratamento deste quadro é um prolongado período de abstinência e "repouso" que, se não for observado, poderá levar à necrose do pênis. Antes disso, entretanto, o jovem já deverá ter sido encaminhado ao atendimento por profissionais da área de saúde mental.

$\mathrm{O}$ vigor de certas relações sexuais podem levar a maior freqüência de fraturas penianas. O uso de "anéis penianos", muito freqüente entre homossexuais, visando aumentar o volume e prolongar o tempo de ereção do pênis, podem levar ao priapismo. Ambas situações são de emergência cirúrgica grave e de conseqüências inestimáveis.

Apesar de, legalmente, só se considerar como estupro a violência e abuso sexual contra o sexo feminino, é cada vez mais freqüente este ato contra jovens do sexo masculino, homossexual ou não, fato que vem acontecendo não só em lugares ermos e escuros, mas até mesmo dentro de casa, pois o perfil do estuprador é, em geral, alguém do círculo de relações ou mesmo um familiar.

Recomenda-se atenção, portanto, àquele profissional de saúde, num serviço de emergência, ao atender um jovem com história de estupro ou lesões anais, que se apresenta totalmente apático e aturdido ou, ao contrário, ansioso e apavorado; histórias mal contadas por parte dos acompanhantes, que se conflitam a cada versão, visando esconder algum fato ou proteger alguém.

Seqüelas de abuso sexual são muito mais graves a nível psicológico e social do que biológico, devendo o paciente ser encaminhado ao serviço de saúde mental e serviço social, garantindo-se a esse jovem o direito de proteção e até mesmo de processar o violador (se conhecido), com bases em laudos periciais, requisitados a serviço da medicina legal em envelopes lacrados que garantam a confidenciabilidade e se resguarde a figura do jovem, mesmo que homossexual. E por que seria diferente? Este foi submetido compulsoriamente a um ato degradante; não inerente ao fato dele ser ou não homossexual, não estando ele, portanto, dispensado de ser brindado com sentimentos de respeito e compaixão que todo e qualquer paciente merece, neste e noutros casos, da parte das autoridades médico-sanitárias, legais e policiais.

\section{Aspectos Referentes à Saúde Mental}

Poucos tópicos permitem tanta diversidade de opiniões (não 
raro se deixando contaminar pelas emoções) quanto a questão da etiopatogenia da homossexualidade. Muitos pontos de vista carregam dentro de si mensagens implícitas quanto a sanidade mental dos portadores desta condição sexual.

As teorias com melhor aceitação sobre o desenvolvimento da personalidade retratam a adolescência como um período evolutivo, talvez o mais crítico de todos no decurso da vida humana. Isto se dá devido à ocorrência de profundas mudanças de caráter bio-fisiológico, psico-intelectual e social, quando também em termos de sua sexualidade estão em jogo questões como o reacordar, reviver, renovar e reposicionar-se, no sentido de adequar os produtos dessas mudanças. Ocorre o aflorar do impulso sexual previamente estabelecido na infância em contrapartida a uma crescente exposição a mensagens de aprovação ou não por pane da sociedade, naquele determinado momento cultural.

Daí o apaixonado desdobrar de questões, como se a homossexualidade fosse uma "anormalidade", tara, aberração ou um mero direcionamento "alternativo" do impulso sexual. Até que ponto seria, por outro lado, uma parada do pleno desenvolvimento geral de uma personalidade adulta? Então, seriam experiências homossexuais na adolescência parte dos degraus a se escalar no sentido da aquisição de uma sexualidade adulta? Até que ponto, e assim o afirmam teorias psicanalíticas (não aceitas por todos os segmentos), não seríamos nós nem totalmente heterossexuais, nem totalmente homossexuais, sendo a expressão (assim como a sublimação) de determinados impulsos uma condicionante de ditames sócio-culturais?

Temas, que se repetem no levantamento da bibliografia tanto de homo quanto de heterossexuais, indicam uma resposta positiva a todas estas perguntas. Neste mesmo levantamento não é difícil encontrar, no estabelecimento de uma conduta homossexual, um processo comum que pode ser dividido em quatro etapas: uma, de confusão na aquisição da identidade sexual; uma, de sensibilização à problemática, seguindo-se do assumir a identidade homossexual, ou seja, adotar essa postura; e, finalmente, o commitment de vivências homossexuais, velada ou abertamente, processo este que também pode ficar interrompido, não chegando a concluir-se obrigatoriamente em todos indivíduos.

Assim sendo, tópicos sobre a saúde mental dos jovens homossexuais são melhor compreendidos no contexto dos limites culturais e históricos, incluindo-se aí também o próprio conceito de adolescência a juventude, assim como a valorização de tópicos como 0 conceito de erotofobia a homofobia do indivóduo e do todo social.

Dentro desses parâmetros, há que se consolidar toda uma 
gama de informações básicas sobre a maneira como vem evoluindo a prática e os estilos de vida dentro da comunidade homossexual a de como a sociedade geral, através de pressões de várias ordens, inclusive legais, atua ou submete esse grupo. E a maneira como, a partir daí, o indivíduo e o grupo homossexual internalizam suas próprias questões da homofobia, as manifestações desse direcionamento sexual, tanto a nível social como psicológico, questões estas que desaguam na sua maior ou menor tranqüilidade frente ao fato de assumir, publicamente ou não, sua condição homossexual.

Necessário é, também, ressaltar que existem grandes diferenças entre indivíduos a grupos de homossexuais, principalmente quando analisadas essas diferenças sob o prisma da homossexualidade masculina e feminina, de jovens ou mais velhos, não ficando essas somente em termos de saúde física mas também em relação às questões de saúde mental.

Há que se considerar, portanto, além dos aspectos terapêuticos específicos a cada caso, sugestões sobre apoio na forma de atendimento na área de serviço social, assim como formação de grupos operativos, fato de extrema importância na alocação de modelos adultos apropriados, acesso, orientação, informação, educação de saúde e aquisição de auxílio mútuo. Isto porque a manutenção da saúde mental deste jovem passa pelo fato deste ter que normalizar suas experiências homossexuais com aquelas referentes à sua experiência como adolescente e, em última análise, como ser humano.

Neste trabalho, esbarra-se no fato de como reagem a família e o meio social, a que este jovem pertence, frente a este "se assumir" como homossexual. Dificuldades de comunicação, comprometimento de auto-estima, sentimentos tanto de culpa como de ódio mal resolvidos são itens que, da parte do jovem, contribuem para essas dificuldades.

Por outro lado, suas famílias são totalmente desinformadas e carregadas de preconceitos em relação à homossexualidade, estando em jogo preceitos religiosos, morais, culturais, a satisfação a dar a nível social, a intensidade das questões que carregam sobre homofobia. Daí surgem influências negativas que revertem no impedimento de um relacionamento menos tumultuado e conflituoso entre as partes envolvidas.

Faz-se, portanto, mister que a equipe de saúde atue não somente sobre o indivíduo, mas também na direção de proporcionar um melhor ajustamento familiar e social, através do uso de estratégias apropriadas, uma vez que assim se permite maior profundidade e duração das ações encetadas do que se agindo somente sobre 0 indivíduo. 
Desta forma, se proporcionará ao jovem homossexual melhores condições de negociar, com sucesso, um espaço para si, constituindo-se este num trabalho profilático e preventivo na preservação de um nível melhor de equilíbrio e saúde mental. Sabidamente a homossexualidade vem acompanhada de muitos sentimentos conflitantes e sofrimentos que só iriam aumentar, se o jovem estiver em meio de uma situação familiar e social confusa a tumultuada. Estas podem se constituir em meio caminho andado para a entrada do jovem em situações de riscos, como depressão e suicídio, fuga de casa e posterior prostituição, por faltar a esse jovem condições de sobrevivência, abuso de álcool e drogas, geralmente associados ao tráfico, infrações criminais e conduta anti-social.

Lembraríamos também dos aspectos especiais sobre tópicos da saúde mental que se associam à condição de doenças crônicas incapacitantes ou de evolução terminal entre jovens, como os portadores de SIDA/AIDS. Morte à doença não fazem parte do repertório do jovem, que se sente traído, pego de surpresa no vigor da juventude, desencadeando uma série de reações psicológicas, como a negação da doença, a revolta, o fazer-se de vítima, o período de barganhas e, só finalmente, um período mais tranqüilo de aceitação do fato, que pode ser obtido mais rapidamente ao se contar com o devido apoio.

Vivendo geralmente sob tensão constante, os jovens homossexuais são também portadores de doenças de cunho psicossomático, que tanto podem se traduzir por síntomatologia indefinida, difusa e imprecisa, como também por quadros definidos: crises enxaquecóides, úlceras pépticas e colites ulcerativas, quadros asmatiformes, quadros dermatológicos, anorexia nervosa e obesidade mórbida, entre outros.

Não gostaríamos de concluir esse tópíco sem mencionar um assunto para o qual o profissional deve estar atento, que é a ocorrência, não tão rara, da chamada "homossexualidade por imposição", quando determinado adolescente é flagrado em situação passiva durante uma experiência homossexual circunstancial. Não sendo este seu direcionamento sexual definitivo, passa a ser cobrado pelos familiares, e principalmente pelos grupos de pares, um desempenho homossexual, uma vez que, mesmo injustamente, foi rotulado como tal. Esta situação gera intenso quadro de angústia e freqüentemente tem desfecho trágico.

\section{CONCLUSÃO}

Frente à exposição deste volumoso material (mesmo numa abordagem superficial, evitando-se discutir cada tema ao nível de 
minúcias), os profissionais que compõem as equipes de saúde que lidam com jovens devem estar atentos a sensíveis à problemática homossexual, devendo, antes de mais nada, examinar, rever seu posicionamento e testar-se frente a uma situação deste tipo. Muitas vezes isto não será fácil e nem mesmo possível de acontecer, pois o profissional, isoladamente ou a equipe como um todo, está também inserido em um contexto social que introjeta, de maneira mais ou menos contundente, uma orientação heterossexualmente determinada. Devemos apenas ser o suficientemente honestos e humildes, passando o caso a um outro profissional mais apto, se, por algum motivo pessoal, tal problemática nos inibe. De nada adiantará mantermos (se conseguirmos) aquele paciente, tratando-o mal, com indiferença, ironia e desrespeito, o que indiretamente constitui-se numa agressão. Esta situação denuncia um intenso mecanismo neurótico de contratransferência que pode até ser a tradução da ameaça de que aquele homossexual à sua frente traga aspectos da própria sexualidade do profissional, não muito bem resolvidos.

Estaríamos sendo injustos ao afirmarmos que o aproach à problemática homossexual se restringe apenas a uma questão unicamente de caráter pessoal, pois na realidade estão envolvidos aspectos até mesmo políticos e ideológicos.

Não pode o profissional, já sensibilizado pela problemática exposta, esquivar-se no sentido da capacitação do restante da equipe e de outros profissionais, visando que estes adquiram melhor compreensão a um posicionamento mais apropriado frente ao jovem homossexual, sob o risco de ver incompleto o seu trabalho.

\section{BIBLIOGRAFIA}

1. OWEN, Jr., W. V. Medical problems of the homossexual adolescents - Sexually active teenagers, their health care. J. A. H. C. 1(3): 1987.

2. SAVIN-WILLIAMS, C. \& RITCH. Theorical perspectives accounting for adolescent homossexuality. J. A. H. C. 9(2): March 1988.

3. TROIDEN, R. R. Homossexual identity development. J. A. H. C. 9(2): March 1988.

4. GONSIOREK, J. C. Mental health issues of gay and lesbian youngsters. J. A, H. C. 9(2): March 1988.

5 . Helping gay and lesbian adolescent and their families: a mother's perspective. J. A. H. C. 9(2): March 1988.

6. ZENILMAN, J. Sexually transmitted diseases in homossexual adolescents. J. A. H. C. 9(2): March 1988. 
7. REMAFEDI, G. J. Preventing the sexual transmission of AIDS during adolescence. J. A. H. C. 9(2): March 1988.

$8 . \quad$. Especial issues on adolescent homossexuality. J. A. H. C. $\overline{9}(\overline{2}):$ March 1988. 